\title{
Potential of phytoremediation using Scirpus validus for domestic waste open dumping leachate
}

\section{${ }^{* 1}$ AWENG, ER; ${ }^{1}$ MUHAMMAD IRFAN, AH; ${ }^{2}$ LIYANA, A.A; ${ }^{1}$ SHARIFAH AISYAH, SO}

\author{
${ }^{I}$ Faculty of Earth Science, Universiti Malaysia Kelantan, Jeli Campus Locked Bag No. 100, 17600 Jeli, Kelantan, Malaysia \\ ${ }^{2}$ Centre for Language Studies and Generic Development, Universiti Malaysia Kelantan(UMK) \\ *Corresponding author: email; aweng@umk.edu.my
}

\begin{abstract}
Currently in Malaysia there are only few sanitary landfills available for domestic waste disposal and most of them are located in Johore, Selangor and Kuala Lumpur. However, to date, there is no sanitary landfill in the state of Kelantan. All the twelve (12) rubbish disposal facilities in Kelantan are open dumping without any treatment. Leachate water was created by decomposition of organic waste flow out and polluted the surface water bodies, soil, ground water and air (smell). Phytoremediation treatment can overcome the water, groundwater, soil and air pollutions from rubbish disposal by using any significant plant either using trees or grassland. The mechanisms such rhizofiltration, phytoextraction, phytostabilization, phytovolatilization and phtodegradation are discussed. This study utilized Scirpus validus, a grass-like plant from Cyperaceae family to treat leachate from open dumping site. It is a fresh water plant that can be found at wetland, shallow water, lake side and wet meadows. The physicochemical parameter is used as an indicator to indicate the effectiveness of Scirpus validus in reducing the concentrations (\%) of $\mathrm{COD}, \mathrm{BOD}_{5}$ and $\mathrm{AN}$. This experiment is conducted only for 15 days due to time constrains. The results showed that, $11.20 \%$ of removing efficiency for $\mathrm{COD}, 30.90 \%$ for $\mathrm{BOD}_{5}$ and $8.70 \%$ for $\mathrm{AN}$. It was believed the removal rate will increase as the treatment time increases. So, it can be concluded that, Scirpus validus has quite substantial potential to be used for open dumping site leachate treatment especially at tertiary treatment or polishing level.
\end{abstract}

DOI: https://dx.doi.org/10.4314/jasem.v22i1.13

Copyright: Copyright (C) 2017 Aweng et al. This is an open access article distributed under the Creative Commons Attribution License (CCL), which permits unrestricted use, distribution, and reproduction in any medium, provided the original work is properly cited

Dates: Received 26 January 2017; received in revised form 15 November 2017; accepted 20 December 2017

Keywords: Scirpus validus, phytoremediation, leachate, domestic waste, open dumping, effectiveness

The study of remediation technology is widely discussed nowadays in order to overcome or treat the contaminated soil, water or even air. There are some examples of remediation technologies such as microbial remediation and phytoremediation where microbial remediation is about microbes as the agent while phytoremediation is about the plants that act as the agent (Nikolić and Stevović, 2015).The growing number of anthropogenic activities and industrialization sectors increase pollutants to the environment thus created various side effects to human health.

One of the activities which created problems to the environment and people, resulted from the increasing number of populations is rubbish disposal site. Currently in Malaysia there are only few sanitary landfills available for domestic waste disposal and most of them are located in Johore, Selangor and Kuala Lumpur, there is no sanitary landfill in Kelantan State. All the twelve (12) rubbish disposal facilities in Kelantan are open dumping without any proper treatment (Aweng and Fatt, 2014). This facility posted leachate which will affect environment components namely surface water, ground water, soil and air. Leachate can be any liquid that has dissolved or entrained environmentally harmful substances that may then enter the environment. It is commonly used in the context of land-filling of putrescible or industrial waste. Leachate can be found as a result of the infiltration process of the precipitation at the landfill. Factors affecting the production of leachate are solid waste composition, operation the mode of a landfill, moisture, temperature and the age of the land fill. All leachate samples are found to contain high concentrations of nitrogen, mainly in the form of ammoniacal nitrogen $\left(\mathrm{NH}_{4}-\mathrm{N}\right)$. Leachates generated in the initial period of waste deposition (up to 5 years) on landfills have $\mathrm{pH} 3.7-6.5$ that reflects the presence of carboxylic acids and bicarbonate ions. With time the leachates become neutral or weakly alkaline ( $\mathrm{pH}$ 7.0-7.6). Landfills exploited for a long period of time give rise to alkaline leachates $(\mathrm{pH} 8.0-$ 8.6). According to Artiola-Fortuny and Fuller (1982), over $60 \%$ of COD content in anaerobic leachates was accounted for by components with structure resembling that of humic compounds.

Rubbish disposal facilities should come along with the air and wastewater treatment system but due to high cost in providing the treatment plant, most of the Local Government opted for open dumping method. 
Open dumping method does not provide any treatment facilities. So, in order to facilitate this problem, many researchers trying to find an alternative which including using plants to remedy the pollution. In this study, aquatic grass dominantly found in the paddy field throughout the Kelantan State namely Scirpus validus was used as remediation to treat rubbish open dumping leachate. Common name of Scirpus validus is great bulrush which can be found largely in muddy area or shallow water level area. Scirpus validus is a rhizomatous cool season perennial with tall dark green with triangular culms. Leaf sheets wrap the culm but blades are insignificant or absent. The stems are topped by pendulous reddish brown umbels. According to New Moon Nursery (2016), Scirpus validus is unbranched perennial sedge that form dense colony from strong rhizomes. For the size, this plant is 8' tall, spongy and triangular green culms. No obvious leaf blades. Culms terminate in a 6 " wide compound umbel. The umbel consists of $1 / 4$ " ovoid rusty brown pubescent scaly spikelet. Each has a single basal bract less than 3" long that appears to be an extension of the culm. The umbel rays are spreading and usually drooping (Figures 1 and 2).

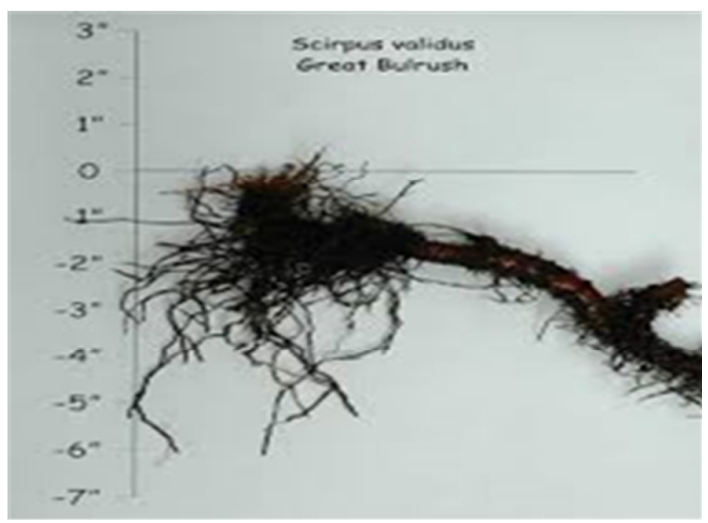

Fig 1: Scirpus validus's root

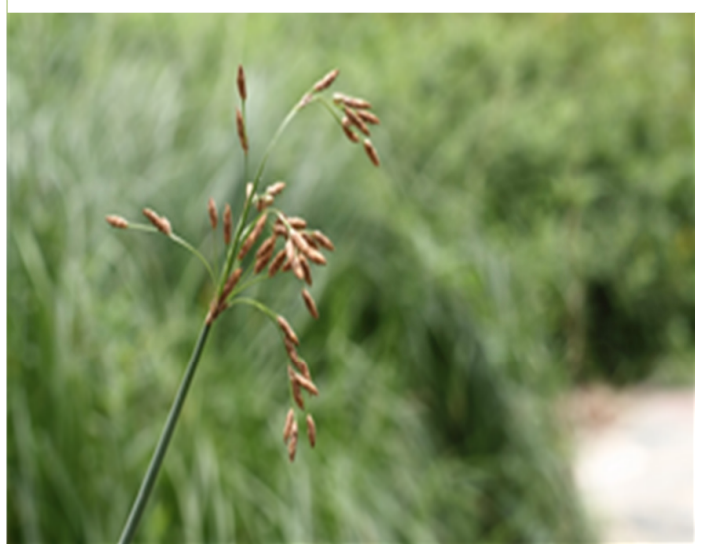

Phytoremediation is not a new created technology in $21^{\text {th }}$ century because this concept has been implemented for the past 300 years on wastewater discharge (Henry, 2000). Phytoremediation has the potential to clean an estimated 30,000 contaminated waste sites throughout the US according to the EPA's Comprehensive Environmental Response Compensation Liability Information System (CERCLIS) and sites included in this estimation are those that have either been owned or contaminated by battery manufacturers, electroplating, metal finishing, and mining companies (Cheek, 1989). Also included in the estimation are producers of solvents, coated glass, paints, leather, and chemicals. The foundation of phytoremediation is built upon the microbial community, and the contaminated soil or water environment. Complex biological, physical, and chemical interactions that occur within the soil allow for the remediation of contaminated sites. The interaction takes place in the soil adjacent to the roots, called the rhizosphere. It has been shown that the rhizosphere contains 10-100 times the number of microorganisms per gram than unvegetated soil.

\section{MATERIALS AND METHODS}

The leachate was collected at leachate pond in the Tumpat District Municipal Open Dumping site located at Kampung Kok Bedollah, Tumpat, Kelantan, Malaysia. Matured Scirpus validus plant with $20 \mathrm{~cm}$ height and its soil is taken from its original site at wet meadowand transferred to each pot respectively for ex-situ treatment. All plants are nursed properly to ensure they are alive for treatment. Scirpus validus are placed at flat area and covered with black net to ensure that the plant growth is not disrupted directly by rainfall, strong wind, weather and animals. The concentrations of chemical oxygen demand (COD), biological oxygen demand (BOD) and ammoniacal nitrogen, $\mathrm{NH}_{4}-\mathrm{N}(\mathrm{AN})$ of leachate before and after treatment was determined. Analysis was conducted in three (3) levels namely after 5 days, 10 days and 15 days. Four (4) composite samples were taken at each pot to become one sample per pot with total of five (5) samples per level. The pot or sample is labelled as FB5 for first batch 5 days treatment, SB10 for second batch 10 days treatment and TB15 for third batch 15 days treatment.

Colorimeter model HACH DR 900 was used to determine the concentrations of BOD, COD and AN before and after treatment. Meanwhile, the removal efficiency or percentage of reduction was calculated using equation (1) below:

$R E=\frac{(\mathrm{WC}-\mathrm{C})}{(\mathrm{WC})} \times 100$

Where: $\mathrm{RE} \quad=$ removal efficiency $(\%), \mathrm{WC}=$ initial value of water quality; parameter (day 0); $\mathrm{C}=$ value of water quality parameter on day 5,10 and 15 .

Fig 2: Scirpus validus's flower 


\section{RESULTS AND DISCUSSION}

The concentrations of raw leachate or leachate before treatment recorded for BOD is $132 \mathrm{mg} / \mathrm{l}, \mathrm{COD}$ is 515 $\mathrm{mg} / \mathrm{l}$ and $\mathrm{AN}$ is $239 \mathrm{mg} / \mathrm{l}$. The temperature and $\mathrm{pH}$ are considered as physical characteristics and the value of $\mathrm{pH}$ recorded is very acidic with the value is 3.63. The abundance of macrophytes and high decomposition of organic matter was able to proof the low values of $\mathrm{pH}$ water in between $3.5-5.5$ (Souza et al., 2013). The decline of $\mathrm{pH}$ value can be due to the presence of facultative bacteria which helps to disintegrate waste and favour the growth of methagonic microorganism, acidogenic bacteria and another chemical content or formation due to hydrolysis and biodegradation process.

The adaptation process of Scirpus validus to its new environment makes phytoremediation process take place. In this remediation technology, phytopumping involved where this mechanism can be used to remove and minimize the migration of the contaminant. Phytopumping pumps a large volume of contaminated water for transpiration process. This can reduce the amount of contaminant in water and large potential uptake (Sridhar Susarla, 2002). Figure 3,4 and 5 shows the concentrations of BOD, COD and AN after they have been treated with Scirpus validus for 5, 10 and 15 days. So, it can be stated that, the concentrations of BOD, COD and AN reduced over period of treatment, the longer the treatment time the higher the reductions. The initial BOD is $132 \mathrm{mg} / \mathrm{L}$, after 5 days of treatment the average concentrations dropped to $129.83 \mathrm{mg} / \mathrm{L}$, after 10 days of treatment the average concentrations further decreased to $98.25 \mathrm{mg} / \mathrm{L}$ and after 15 days of treatment the average concentrations decreased to $91.22 \mathrm{mg} / \mathrm{L}$ (Figure 3). The concentration of BOD reduced by $2.17 \mathrm{mg} / \mathrm{L}, 33.75 \mathrm{mg} / \mathrm{L}, 40.78 \mathrm{mg} / \mathrm{L}$ after 5 days, 10 days and 15 days of treatment respectively.

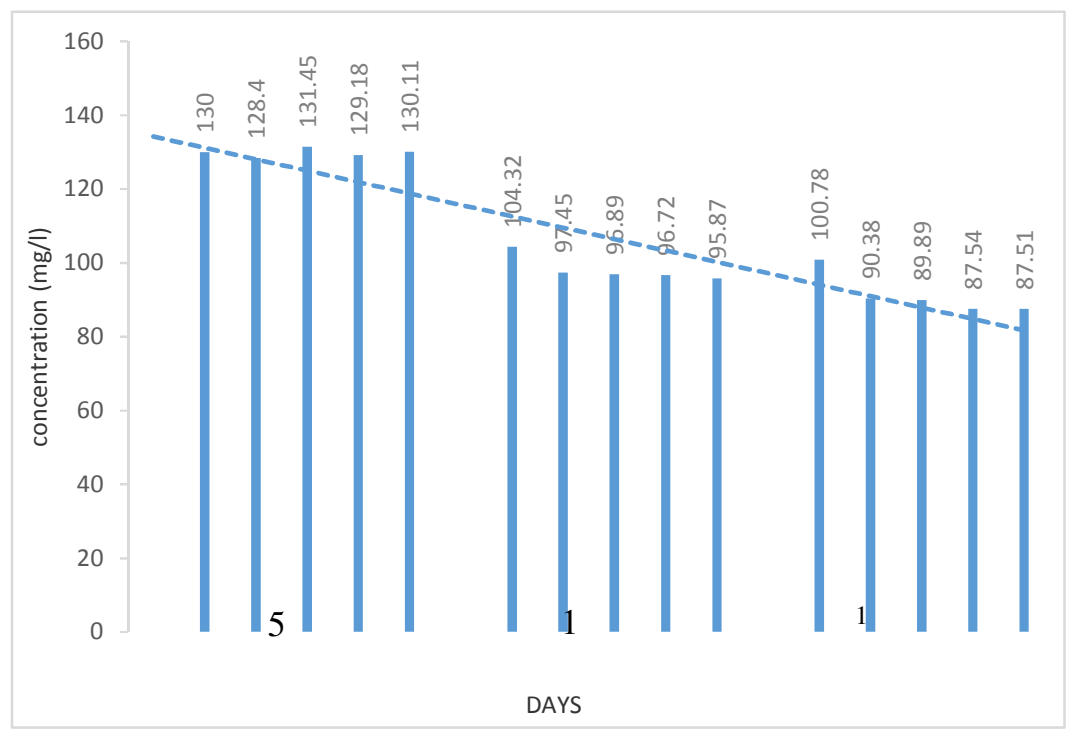

Fig 3: Concentration of BOD against treatment time

The initial COD is $515 \mathrm{mg} / \mathrm{L}$, after 5 days of treatment the average concentrations dropped to $512.22 \mathrm{mg} / \mathrm{L}$, after 10 days of treatment the average concentrations further decreased to $477.70 \mathrm{mg} / \mathrm{L}$ and after 15 days of treatment the average concentrations decreased to $457.52 \mathrm{mg} / \mathrm{L}$ (Figure 4). The concentration of COD reduced by 2.78 $\mathrm{mg} / \mathrm{L}, 37.30 \mathrm{mg} / \mathrm{L}, 57.48 \mathrm{mg} / \mathrm{L}$ after 5 days, 10 days and 15 days of treatment respectively.

The initial AN is $239 \mathrm{mg} / \mathrm{L}$, after 5 days of treatment the average concentrations dropped to $237.24 \mathrm{mg} / \mathrm{L}$, after 10 days of treatment the average concentrations further decreased to $231.51 \mathrm{mg} / \mathrm{L}$ and after 15 days of treatment the average concentrations decreased to $218.32 \mathrm{mg} / \mathrm{L}$ (Figure 5). The concentration of AN reduced by 1.76 $\mathrm{mg} / \mathrm{L}, 7.49 \mathrm{mg} / \mathrm{L}, 20.68 \mathrm{mg} / \mathrm{L}$ after 5 days, 10 days and 15 days of treatment respectively.

As the time increases following the phytoremediation process, the removal efficiency is corresponding increased.Figure6 shows the percentage of removal efficiency (RE) for each parameters. The percentage of removal for BOD is higher compared to COD and AN with $30.9 \%$. It could be concluded that, Scirpus validus has great potential in controlling BOD concentration compared to COD (11.20\%) and AN (8.70\%). 
High removal rates of BOD could be caused by oxidation of organic matter in leachate water that provides energy for microbial metabolism (Prabu and Udayasooriyan, 2007). The organic matter contained in the leachate water provides a substrate for aerobic microbial metabolism and the length of phytoremediation time (Zhang et al., 2006) could lead to a decrease of BOD concentration.

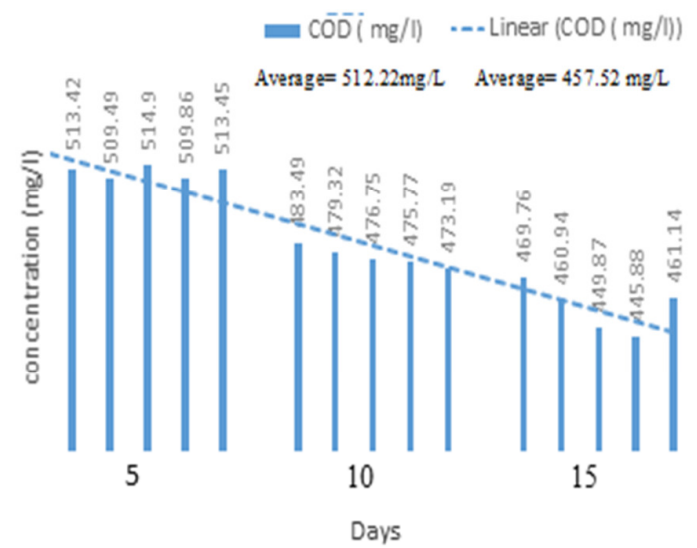

Fig 4: Concentration of $\mathrm{COD}$ against treatment time

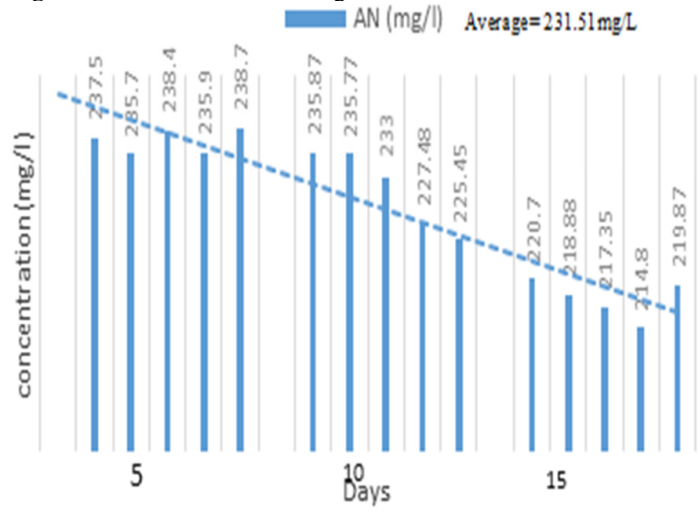

Fig 5: Concentration of AN against treatment time

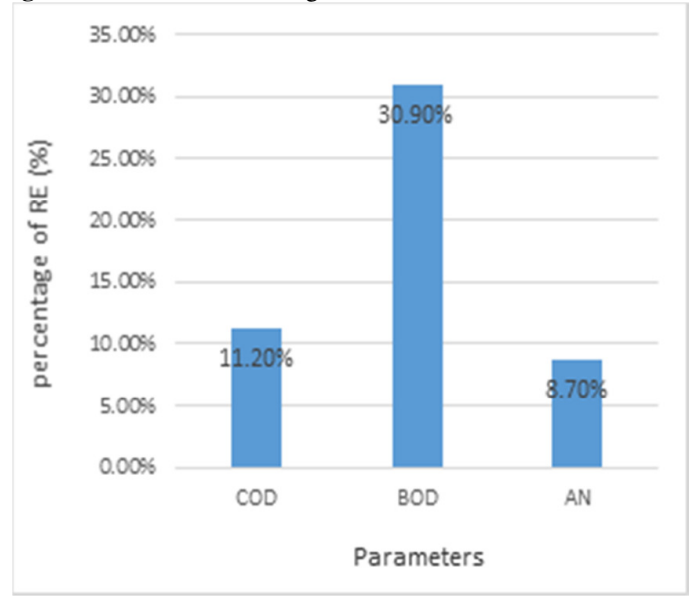

Fig 6: Percentage of removal efficiency after 15 days
Conclusion: The results showed a substantial rate of reduction in $\mathrm{BOD}_{5}$ but not in $\mathrm{COD}$ and $\mathrm{AN}$ after 15 days of treatment. So, it can be concluded that, Scirpus validus could be an alternative to reduce nutrient and organic matter in leachate water. Among these three parameters analysed, the rate of AN was the lowest compared to COD and BOD. It is due to the properties of the soil, microbes, nitrifying bacteria to adapt the changes for the first time the soil receives landfill leachate. A combination of chemical from the leachate and the biological process is likely to govern the fate of nitrogen in that system. Other factors such as amount of precipitation and temperature were also believed to influence the pollutants reduction rate. High temperature can disrupt the microorganism activity and the properties. However, the percentage of reduction recorded is only based on one plant in a treatment pot and 15 days of treatment, the reduction rate are expected to be higher with increasing number of plants and longer treatment period.

Acknowledgement: We are grateful to the management of the Faculty of Earth Science, Universiti Malaysia Kelantan (UMK) for facilitating the research in terms of lab facilities and chemicals for the completion of this study.

\section{REFERENCES}

Nikolić, M. and Stevović, S. (2015). Family Asteraceae as a sustainable planning tool in phytoremediation and its relevance in urban areas. Urban Forestry and Urban Greening. 14(4):782-789.

Aweng,E.R. and Fatt, C.C. (2014). Perception of Rubbish Collectors at the Garbage Dump Sites in Kelantan, Malaysia on the use of Personal Protective Equipments (PPE). Health and the Environment Journal. 5(3): 53-65.

Artiola-Fortuny and Fuller (1982). Humid acids in municipal solid waste leachates. Journal of Environmental Quality. Soil Science. 133:1826.

New Moon Nursery (2017). Scirpus validus (tabernaemontani): Soft stemmed bulrush. Retrieved on $19^{\text {th }}$ of January, 2017 from http://www.newmoonnursery.com/plant/Scirpu s-validus-tabernaemontani

Henry, J.R. (2000). An Overview of the Phytoremediation of Lead and Mercury. Washington D.C: National Network of Environmental Management Studies. 
Cheek, L. (1989). Insurance Issues Associated with Cleaning up Inactive Hazardous Waste Sites. 14(51), 120-148.

Souza, F. A., Dziedzic, M., Cubas, S. A. and Maranho, L. T. (2013). Restoration of polluted waters by phytoremediation using Myriophyllum aquaticum (Vell.) Verdc., Haloragaceae. Journal of environmental management. 120, 5-9.
Prabu, P.C. and Udayasooriyan, C. (2007). Treatment of Pulp and Paper

Mill Effluent Using Constructed Wetland. Electronic Journal of Enviromental, Agricultural and Food Chemistry. 6(1):16891701.

Zhang, X.B., Liu, P., Yang, Y.S. and Chen, W.R. (2007). Phytoremediation of Urban Wastewater by Model Wetlands with Ornamental Hydrophytes. Journal of Environmental Sciences. 19(8):902-909. 